\title{
The use of ecosystem services valuation in Australian coastal zone management
}

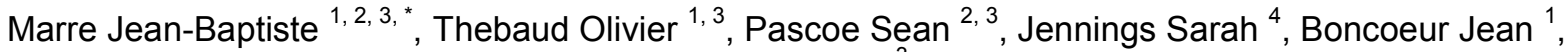 \\ Coglan Louisa ${ }^{3}$
}

${ }^{1}$ IFREMER, AMURE, Unite Econ Maritime, UMR M101, Brest, France.

${ }^{2}$ CSIRO Wealth Oceans Flagship, Marine \& Atmospher Res, Brisbane, QId, Australia.

${ }^{3}$ Queensland Univ Technol, Sch Econ \& Finance, Brisbane, Qld 4001, Australia.

${ }^{4}$ Univ Tasmania, Tasmanian Sch Business \& Econ, Hobart, Tas, Australia.

* Corresponding author : Jean-Baptiste Marre, Tel: +687 262000. ;

email address : jean-baptistem@spc.int

\begin{abstract}
:
The use and influence of ecosystem services valuation in management decision-making, particularly as it relates to coastal zone management, remains largely unexplored in the academic literature. A recent Australia-wide survey of decision-makers involved in coastal zone management examined if, how and to what extent economic valuation of coastal and marine ecosystem services is used in, and influences, decision-making in Australia. The survey also identified a set of cases where economic valuation of ecosystem services was used for decision-making, and reasons why economic values may or may not be considered in the decision-making process. This paper details the method and results from this survey. Overall, there is strong empirical evidence that economic valuation of ecosystem services is used, but with important variation across coastal and marine management contexts. However, the impact of ecosystem services valuation on policy appears to be globally weak
\end{abstract}

Keywords : Coastal zone management, Decision-making, Ecosystem services, Economic valuation 


\section{Introduction}

Economic valuation methods applied to ecosystem services are now well established in many areas of application. The increasing development of the Ecosystem Services economic Valuation (ESV) approach has been fuelled by the growing need to deal with ecosystem degradation globally, and valuation studies have increasingly been advocated to support decision-making and management. Coastal and marine ecosystems (CME) are some of the most heavily exploited ecosystems globally, with intense and increasing degradation. This situation requires urgent and effective management action, and has prompted increasing calls for more coastal and marine ESV to guide policy (Laurans et al., 2013a; Barbier, 2012; Schuman 2011; Brander et al., 2007, Pendleton et al., 2007).

Despite this growing interest and the efforts to facilitate the inclusion of ESV in decisionmaking (Waite, R., et al. 2014; Balmford et al., 2011; de Groot et al., 2010; Liu et al., 2010; Daily et al., 2009; Fisher et al., 2009; TEEB, 2008; Pendleton et al., 2007), there is still a paucity of academic literature examining the actual utilization of economic valuation by decision-makers (Laurans et al., 2013b; Rogers et al., 2013): what value estimates are actually used, how are they used (for what specific purpose, in which decision context and by whom) and to what extent are they used remain unanswered questions. In fact, it is uncommon to find a detailed explanation of the actual or potential use of the values that were estimated in valuation studies (Laurans et al., 2013b). Usually methods are described, values are estimated, and presented as potentially useful, with little discussion of the actual decision-making contexts where these will/could be used, and with no indication of whether they are produced in response to a specific management support need. In short, the ultimate influence of ESV on policy, management, or investment remains largely unknown. 
This issue, which is of particular concern in Australia where a substantial amount of ESV work has been conducted in the last decades (e.g. Bennett, 2011), including in the coastal and marine domains (e.g. Stoeckl et al., 2011), has recently been identified as an important research question (e.g. Rogers et al., 2013).

This paper provides the first Australia-wide and expert-based review of the cases in which ESV has been used in support of coastal zone management. Information on which the review is based is derived from a survey of management stakeholders carried out with the broader aim of eliciting the perception of ESV's usefulness in the context of coastal zone management.

\section{The survey}

A nation-wide online survey was designed in order to represent the responses of the diversity of stakeholders involved in coastal zone management in different regional, State and Federal contexts of Australia, while minimizing the costs of the approach. A list of more than four hundred decision-makers involved in coastal zone management was developed. Decisionmakers refer to individuals directly involved in the decision-making process regarding coastal and marine areas management in either an informative (collating information or delivering it to others), consultative (providing advice and recommendations to others), contributive (contributing to the final decision and/or management plan) or decisive way (deciding whether or not a decision is implemented). The list included:

- Members of governmental departments and associated agencies/bodies at both national and State levels;

- Members of regional and local governments and committees;

- Representatives of major marine industries or maritime activities (e.g. recreational or commercial fishing); 
- Researchers (from different research organizations) who are part of coastal management committees or consultation processes ${ }^{1}$.

The questionnaire included several sections, as well as a glossary for the specific terminology used. This paper focuses on the results of the section in which respondents document actual utilization of ESV in coastal zone management. Questions in this section focused on the extent to which respondents considered ESV during a decision-making process (often, rarely or never) in which they took part, for each of the different management contexts they were involved in. For each context for which respondents declared ESV was used, they were asked to differentiate between three types of utilization: ESV as a way to communicate, advocate and raise awareness; ESV for evaluation and decision-making (e.g. cost benefit analysis) and ESV as a basis for establishing taxes, subsidies, fees or damage compensation (Laurans et al., 2013b)

An additional set of questions focused on whether respondents knew of ESV studies for marine and coastal ecosystems that did have a significant impact on policy or management in a specific region, and about decision-making processes where ESV information existed but was not used. The reasons why it was not used were identified and respondents canvassed as to whether they thought that ESV should be used more in decision-making.

For each question, respondents were asked to provide at least one example with, if possible, a reference to a publication. This was crucial to collect concrete examples of what respondents had in mind when mentioning utilization of ESV. In addition, responses to this question were

1 These individuals can be considered as decision-makers since they are directly involved in the decision-making process. In total 15 researchers answered the survey entirely, and five of them had an educational and/or professional background in social sciences, economics, business or management. Most of the individuals in this group did not appear to be involved in producing ESV, and all were potential ESV users. 
also intended to help compile a list of cases where ESV had been used, which, with the associated set of study references, is the focus of this paper.

The survey took place in October 2013, and was completed by 88 stakeholders. Characteristics of the respondents are summarized in Table 1.

Table 1 Characteristics of survey respondents

\begin{tabular}{|c|c|}
\hline Characteristic & Survey response \\
\hline Age (Average based on categories) & 42 yo \\
\hline \multicolumn{2}{|l|}{ Gender } \\
\hline - Male & $70 \%$ \\
\hline - Female & $30 \%$ \\
\hline \multicolumn{2}{|l|}{ Level of education } \\
\hline - Advanced Diploma and Diploma & $9 \%$ \\
\hline - Bachelor Degree & $27 \%$ \\
\hline - Graduate Diploma or Graduate Certificate & $9 \%$ \\
\hline - Postgraduate Degree & $55 \%$ \\
\hline \multicolumn{2}{|l|}{ Field of education ( $\%$ of respondents indicating category) } \\
\hline - Natural and physical science & $33 \%$ \\
\hline - Agriculture \& environmental studies & $36 \%$ \\
\hline - Management and commerce & $10 \%$ \\
\hline - Society and culture & $9 \%$ \\
\hline - Engineering and technologies & $6 \%$ \\
\hline - Other & $6 \%$ \\
\hline \multicolumn{2}{|l|}{ Work experience ( $\%$ of respondents indicating category) } \\
\hline - Environmental management & $92 \%$ \\
\hline - Biological conservation & $51 \%$ \\
\hline - Economics & $22 \%$ \\
\hline - Business & $20 \%$ \\
\hline - Finance & $7 \%$ \\
\hline \multicolumn{2}{|l|}{ Geographic location } \\
\hline - New South Wales & $28 \%$ \\
\hline - Victoria & $8 \%$ \\
\hline - Queensland & $15 \%$ \\
\hline - South Australia & $13 \%$ \\
\hline - Western Australia & $16 \%$ \\
\hline - $\quad$ Northern Territory & $5 \%$ \\
\hline - Tasmania & $9 \%$ \\
\hline - $\quad$ Australian Capital Territory & $6 \%$ \\
\hline
\end{tabular}


The sample was highly diverse in terms of field of education, work experience and geographical location. In total 88 per cent of respondents were currently working for government and associated agencies: 70 per cent in policy and management and 18 per cent in research. A further 17 per cent were working for non-governmental research and higher education, and three per cent of the sample identified themselves as industry representatives. Eight per cent of the respondents declared being involved in other organizations, such as management committees; or working as private consultants. The work of respondents related to all jurisdictions (all States as well as the Federal level) and focused on a wide range of management contexts in total 58 per cent of individuals declared working on marine areas and species conservation, 48 per cent on coastal development, 39 per cent on recreational activities and tourism, 25 per cent on coastal and marine pollution, 24 per cent on commercial fisheries and 14 per cent on indigenous and customary use.

Figure 1 shows the distribution of respondents across management contexts for each of the eight jurisdictions.

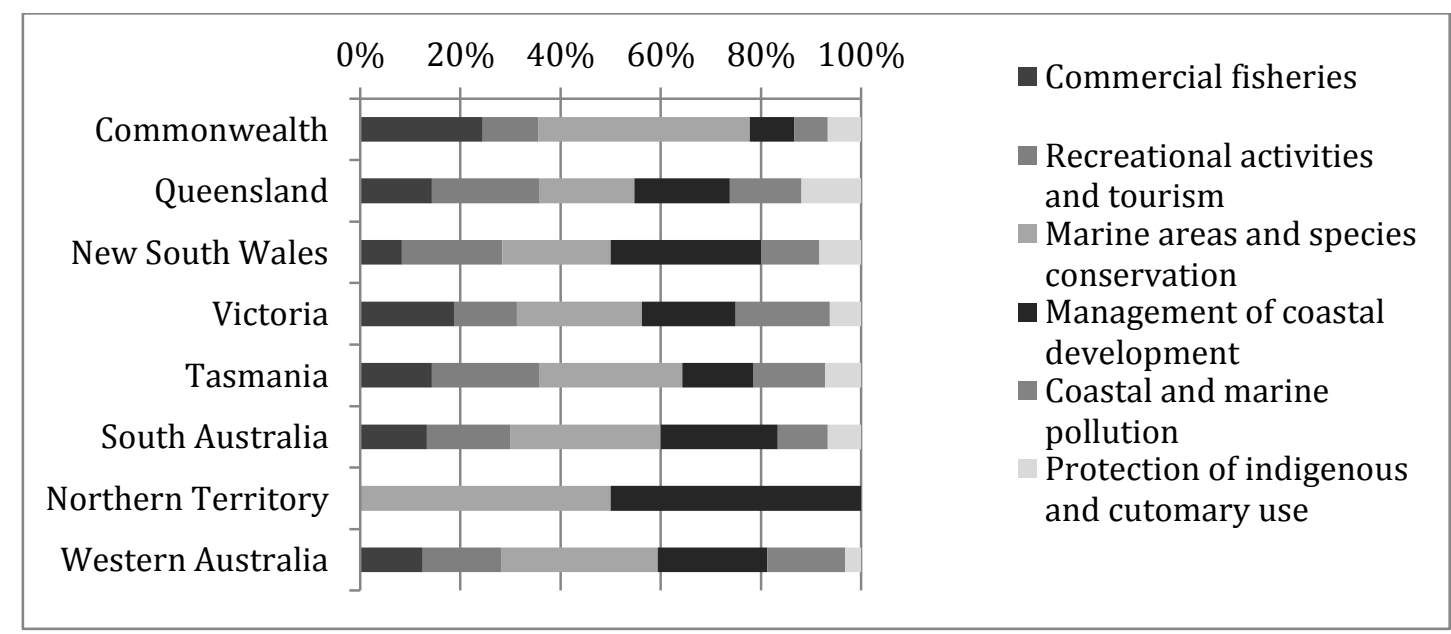

${ }^{\dagger}$ The list of management contexts is ordered from the left hand side (commercial fisheries) to the right hand side of the figure (protection of indigenous use)

Figure 1 Jurisdictions in which respondents were involved in management decision-making, by management context 
Respondents also varied in terms of years of experience in coastal zone management 26 per cent stated between zero and five years of experience, 22 per cent between six and 10 years, 24 per cent between 11 and 20 years and 28 per cent more than 20 years.

The respondents were asked to select at least one option that would best describe their role in decision-making among four possible roles. 60 per cent declared having an informative role, 68 per cent a consultative role, 66 per cent a contributive role, and 33 per cent a decisive role. The two latter categories of respondents (with a contributive and decisive role) could be considered to represent those who effectively "make decisions". $90 \%$ of these individuals were working for government and associated agencies, while $6 \%$ were involved in research activities (for government or non-governmental organization). $20 \%$ of them had a professional background in economics, $30 \%$ in business or finance, and $35 \%$ had more than 20 years of experience in decision-making.

\section{ESV use in coastal management}

Out of the 88 decision-makers who completed the survey, 52 declared having used ESV, while 30 declared being only familiar with it. Five declared having only heard about it.

Table 2 below summarizes the frequency of ESV use across the six management contexts as stated by respondents. Appendix A provides details on the frequencies, including "Do not know" responses.

On average, across all management contexts, ESV seemed to be rarely considered. Besides, results show overall that ESV was used slightly more for communication and advocacy than for evaluation and decision-making, and rarely to set up economic and financial instruments.

The absence of significant differences in the average stated frequency scores between "ESV for communication and advocacy" and "ESV for evaluation and decision-making" could mean that these two response categories might have seemed vague to some respondents. 
However, none of them mentioned this issue in their comments on the survey. In addition, differences in the frequencies of "Do not know" responses were actually observed (appendix A), which indicates that some distinction between the response categories occurred.

Table 2 Average stated frequency scores ${ }^{\dagger}$ for the different types of ESV use and management contexts

\begin{tabular}{rrrrrrr}
\hline & $\begin{array}{c}\text { ESV for } \\
\text { communication } \\
\text { and advocacy }\end{array}$ & $\begin{array}{c}\text { ESV for } \\
\text { evaluation and } \\
\text { decision-making }\end{array}$ & \multicolumn{2}{c}{$\begin{array}{c}\text { ESV for } \\
\text { economic and } \\
\text { financial } \\
\text { instruments }\end{array}$} \\
\hline Mean & s.d. & Mean & s.d. & Mean & s.d. \\
\hline Commercial fisheries & 2.43 & 0.73 & 2.43 & 0.73 & 2.08 & 0.65 \\
Recreational activities and & & & & & & \\
Coastal development & 2.26 & 0.65 & 2.24 & 0.65 & 1.6 & 0.49 \\
Marine areas and species & 2.1 & 0.74 & 2.1 & 0.73 & 1.54 & 0.71 \\
conservation & 2 & 0.82 & 2 & 0.79 & 1.64 & 0.63 \\
Coastal and marine pollution & 1.82 & 0.89 & 1.82 & 0.81 & 1.57 & 0.79 \\
Indigenous and customary use & 1.25 & 0.44 & 1 & 0 & 1 & 0 \\
\hline 1=Never considered; 2= Rarely considered; 3=Often considered & & & & & \\
\hline
\end{tabular}

The management context in which ESV was most often considered (across all categories of use) was the management of commercial fisheries. Relatively high standard deviations indicated a significant variation of stated frequency of use, although this was lower in the case of ESV for economic and financial instruments.

Table 3 details these results by categories of users: policy-makers and managers working for governments and associated agencies, researchers working for governmental or nongovernmental research and higher education organisations, and marine industry representatives. 
Table 3 Average stated frequency scores $^{\dagger}$ for the different types of ESV use and management contexts, by categories of users

\begin{tabular}{|c|c|c|c|c|c|c|c|c|c|}
\hline \multirow{2}{*}{$\begin{array}{c}\text { Users } \\
\text { ESV for }\end{array}$} & \multicolumn{3}{|c|}{$\begin{array}{l}\text { Governments and associated agencies: policy- } \\
\text { makers and managers }\end{array}$} & \multicolumn{3}{|c|}{ Researchers $^{\dagger \dagger}$ taking part in decision-making } & \multicolumn{3}{|c|}{ Marine industry representatives } \\
\hline & $\begin{array}{l}\text { Communication } \\
\text { and advocacy }\end{array}$ & $\begin{array}{l}\text { Evaluation and } \\
\text { decision-making }\end{array}$ & $\begin{array}{c}\text { Economic and } \\
\text { financial } \\
\text { instruments }\end{array}$ & $\begin{array}{l}\text { Communication } \\
\text { and advocacy }\end{array}$ & $\begin{array}{l}\text { Evaluation and } \\
\text { decision-making }\end{array}$ & $\begin{array}{c}\text { Economic and } \\
\text { financial } \\
\text { instruments }\end{array}$ & $\begin{array}{l}\text { Communication } \\
\text { and advocacy }\end{array}$ & $\begin{array}{l}\text { Evaluation and } \\
\text { decision-making }\end{array}$ & $\begin{array}{c}\text { Economic and } \\
\text { financial } \\
\text { instruments }\end{array}$ \\
\hline $\begin{array}{l}\text { Commercial } \\
\text { fisheries }\end{array}$ & $\begin{array}{l}\mathbf{2 , 2 5} \\
(0.83)\end{array}$ & $\begin{array}{c}\mathbf{2 , 0 0} \\
(1)\end{array}$ & $\begin{array}{c}\mathbf{1 , 7 5} \\
(0.83)\end{array}$ & $\begin{array}{l}\mathbf{2 , 6 7} \\
(0.47)\end{array}$ & $\begin{array}{l}\mathbf{2 , 6 7} \\
(0.47)\end{array}$ & $\begin{array}{c}\mathbf{2 , 0 0} \\
(0)\end{array}$ & $\begin{array}{l}\mathbf{2 , 5 0} \\
(n a)\end{array}$ & $\begin{array}{l}\mathbf{2 , 5 0} \\
(n a)\end{array}$ & $\begin{array}{l}\mathbf{2 , 5 0} \\
(n a)\end{array}$ \\
\hline $\begin{array}{c}\text { Recreational } \\
\text { activities and } \\
\text { tourism }\end{array}$ & $\begin{array}{c}\mathbf{2 , 2 1} \\
(0.69)\end{array}$ & $\begin{array}{c}\mathbf{2 , 2 2} \\
(0.72)\end{array}$ & $\begin{array}{c}\mathbf{1 , 4 7} \\
(0.50)\end{array}$ & $\begin{array}{l}\mathbf{2 , 2 5} \\
(0.43)\end{array}$ & $\begin{array}{c}\mathbf{2 , 0 0} \\
(0)\end{array}$ & $\begin{array}{c}\mathbf{2 , 0 0} \\
(0)\end{array}$ & $\begin{array}{l}\mathbf{2 , 0 0} \\
(n a)\end{array}$ & $\begin{array}{l}\mathbf{2 , 0 0} \\
(n a)\end{array}$ & \\
\hline $\begin{array}{c}\text { Coastal } \\
\text { development }\end{array}$ & $\begin{array}{c}\mathbf{2 , 0 4} \\
(0.84)\end{array}$ & $\begin{array}{c}\mathbf{2 , 1 7} \\
(0.76)\end{array}$ & $\begin{array}{l}\mathbf{1 , 5 2} \\
(0.65)\end{array}$ & $\begin{array}{l}\mathbf{1 , 5 0} \\
(n a)\end{array}$ & $\begin{array}{l}\mathbf{1 , 0 0} \\
(n a)\end{array}$ & $\begin{array}{l}\mathbf{1 , 0 0} \\
(n a)\end{array}$ & $\begin{array}{c}\mathbf{2 , 0 0} \\
(n a)\end{array}$ & $\begin{array}{l}\mathbf{1 , 0 0} \\
(n a)\end{array}$ & $\begin{array}{l}\mathbf{1 , 0 0} \\
(n a)\end{array}$ \\
\hline $\begin{array}{l}\text { Marine areas } \\
\text { and species } \\
\text { conservation }\end{array}$ & $\begin{array}{l}\mathbf{2 , 0 0} \\
(0.76)\end{array}$ & $\begin{array}{l}\mathbf{2 , 0 0} \\
(0.71)\end{array}$ & $\begin{array}{c}\mathbf{1 , 6 1} \\
(0.68)\end{array}$ & $\begin{array}{l}\mathbf{2 , 0 0} \\
(0.53)\end{array}$ & $\begin{array}{l}\mathbf{1 , 8 3} \\
(0.69)\end{array}$ & $\begin{array}{l}\mathbf{1 , 6 7} \\
(0.74)\end{array}$ & $\begin{array}{l}\mathbf{2 , 0 0} \\
(n a)\end{array}$ & $\begin{array}{c}\mathbf{2 , 0 0} \\
(n a)\end{array}$ & \\
\hline $\begin{array}{c}\text { Coastal and } \\
\text { marine pollution }\end{array}$ & $\begin{array}{c}\mathbf{1 , 7 3} \\
(0.86)\end{array}$ & $\begin{array}{l}\mathbf{1 , 6 4} \\
(0.77)\end{array}$ & $\begin{array}{c}\mathbf{1 , 4 5} \\
(0.78)\end{array}$ & $\begin{array}{c}\mathbf{2 , 0 0} \\
(0.82)\end{array}$ & $\begin{array}{c}\mathbf{2 , 0 0} \\
(0.82)\end{array}$ & $\begin{array}{l}\mathbf{1 , 6 7} \\
(0.94)\end{array}$ & & & \\
\hline $\begin{array}{l}\text { Indigenous and } \\
\text { customary use }\end{array}$ & $\begin{array}{l}\mathbf{1 , 1 7} \\
(0.37)\end{array}$ & $\begin{array}{c}\mathbf{1 , 0 0} \\
(0)\end{array}$ & $\begin{array}{c}\mathbf{1 , 0 0} \\
(0)\end{array}$ & $\begin{array}{l}\mathbf{1 , 0 0} \\
(n a)\end{array}$ & $\begin{array}{l}\mathbf{1 , 0 0} \\
(n a)\end{array}$ & $\begin{array}{l}\mathbf{1 , 0 0} \\
\text { (na) }\end{array}$ & & & \\
\hline
\end{tabular}

${ }^{\dagger} 1=$ Never considered; $2=$ Rarely considered; $3=$ Often considered

${ }^{\dagger \dagger}$ Working for governmental or non-governmental research and higher education

na: not applicable (less than three respondents) 
Differences were observed between the three categories of respondents. ESV was most frequently used by researchers in the context of commercial fisheries management, followed by marine industry representatives. In the other management contexts, on average, policymakers and managers from governments and associated agencies were those who stated higher frequency of ESV use, for most types of utilization (except for coastal and marine pollution).

When asked whether they thought that ESV should be used more often in coastal and marine decision-making and if so, for what kind of values, 81 per cent of respondents answered positively (three per cent "No" and 16 per cent "Do not know"), in assessing commercial use values (75 per cent), recreational use values (70 per cent), indirect use values - especially regulating services (98 per cent) - and non-use values ( 71 per cent).

Around 80 examples where ESV has been used were collected through the survey; some with precise references to specific ESV studies, others with limited comments on how ESV was used. Table 4 summarizes the 40 cases for which detailed information was provided by respondents ${ }^{2}$. These, as well as the other examples cited by respondents, are representative of the range of management contexts and types of ESV use. The list of applications includes engaging with communities in marine conservation, planning marine park zoning and management (e.g. preparation and implementation of management plan), setting fisheries management targets (at the Commonwealth, States and specific marine areas levels), evaluating impact (change in economic values) of conservation measures on fisheries and other marine activities, justifying the protection of habitats (seagrass and mangroves) or species based on their economic value, weighing up the costs/benefits of economic

\footnotetext{
${ }^{2}$ The other examples cited by respondents are not presented in this paper due to a lack of precision in their citations that did not allow proper characterization.
} 
development in policy making (e.g. shipping ports) or of various and sometimes competing management options, helping policy-making to assess competing values in coastal development, discussing the importance of maintaining or improving estuary health and selecting appropriate responses to coastal hazards, and helping assess or even compensate the impact of various terrestrial activities on habitats, species or marine activities.

Specific ESV studies addressing marine and coastal ecosystems values that were perceived as having significantly impacted policy or management are presented in Table 5. Only 25 per cent of the respondents (out of the 71 decision-makers that answered this question) declared they were aware of such works, while 63 per cent declared they were not aware of any such studies and the remaining 13 per cent did not know. Among the respondents who declared being aware of such works, $60 \%$ were policy-makers and managers, $30 \%$ researchers, $10 \%$ representatives from marine industry. 
Table 4 Australian cases of ESV use by management context and types of uses identified by coastal and marine decision-makers

\begin{tabular}{|c|c|c|c|}
\hline & $\begin{array}{c}\text { ESV as a way to communicate, advocate or } \\
\text { raise awareness }\end{array}$ & ESV for evaluation and decision-making & $\begin{array}{c}\text { ESV for establishing taxes, subsidies, fees } \\
\text { or damage compensation }\end{array}$ \\
\hline $\begin{array}{l}\text { Commercial } \\
\text { fisheries }\end{array}$ & $\begin{array}{l}\text { - Queensland, Great Barrier Reef Marine Park } \\
\text { (GBRMPA): } \\
\text { 2006-07 Access Economics report. Measuring } \\
\text { the economic \& financial value of the Great } \\
\text { Barrier Reef Marine Park } \\
\text { - Western Australia: Western Rock Lobster } \\
\text { Fisheries Maximum Economic Yield } \\
\text { considerations in the fisheries management } \\
\text { - South Australia: incorporating economic aspects } \\
\text { of fisheries into the development of } \\
\text { management plans }\end{array}$ & $\begin{array}{l}\text { - Queensland, Great Barrier Reef Marine Park } \\
\text { (GBRMPA): } \\
\text { 2006-07 Access Economics report to GBRMPA } \\
2000 \text { Planning for GBR Representative Areas } \\
\text { - South Australia, Pipi fishery, 2013: setting Total } \\
\text { Allowable Commercial Catch } \\
\text { - Southern Rock Lobster Fisheries harvest strategy } \\
\text { evaluation }\end{array}$ & $\begin{array}{l}\text { - Southern and Eastern Scalefish and Shark } \\
\text { Fisheries: ESV used to consider economic } \\
\text { incentives (e.g. Hutton et al., 2010) } \\
\text { - South Australia, 2013: buy-back of } \\
\text { commercial fishing activity due to } \\
\text { establishment of marine parks } \\
\text { Econsearch et al.. 2012. Marine Park } \\
\text { Regional Impact Statements. Main Report. } \\
\text { - Southwest Marine Region Commonwealth } \\
\text { Marine Reserves Network, 2012-2013: } \\
\text { quotas and license buy-out } \\
\text { Australian Bureau of Agricultural and } \\
\text { Resource Economics and Sciences report. } \\
\text { 2012. Social and economic assessment of } \\
\text { the impacts on commercial and charter } \\
\text { fishing. }\end{array}$ \\
\hline $\begin{array}{l}\text { Recreational } \\
\text { activities and } \\
\text { tourism }\end{array}$ & $\begin{array}{l}\text { - State-wide Beach and Surf Tourism and } \\
\text { Recreation Values studies from Bond and } \\
\text { Griffith University (e.g. Anning et al., 2013) } \\
\text { - State-wide recreational fishing evaluation } \\
\text { (Raguragavan et al., 2013) }\end{array}$ & $\begin{array}{l}\text { - Western Australia: Ningaloo reef fisheries management } \\
\text { arena (e.g. Gao and Hailu, 2011) } \\
\text { - South Australia, 2013: Closure of snapper fishing to all } \\
\text { sectors including recreational fishing }\end{array}$ & $\begin{array}{l}\text { - Queensland, Gold Coast, 2005: } \\
\text { Infrastructure charging Stormwater } \\
\text { Quality }\end{array}$ \\
\hline
\end{tabular}




\begin{tabular}{|c|c|c|c|}
\hline & $\begin{array}{l}\text { - Queensland, Gold Coast, 1998: benefits and } \\
\text { costs for beach nourishment, Surfers Paradise } \\
\text { - Queensland, GBRMPA: } \\
\text { 2012/2013 Deloitte Access Economics reports. } \\
\text { Economic contribution of the Great Barrier } \\
\text { Reef. } \\
2006 \text { and beyond zoning of marine park Stoeckl } \\
\text { et al., } 2011 \\
\text { - Victoria, Portland, 2011: estimation of the } \\
\text { Recreational Use Value Gained from } \\
\text { Recreational Fishing of Southern Bluefin Tuna } \\
\text { (Ezzy and Scarborough, 2011) }\end{array}$ & $\begin{array}{l}\text { - Queensland, GBRMPA: } \\
\text { 2012/2013 Deloitte Access Economics reports. Economic } \\
\text { contribution of the Great Barrier Reef. } \\
\text { Stoeckl et al., } 2011 \\
\text { - South Australia: considered in developing new water } \\
\text { quality policy } \\
\text { • New South Wales, Clarence Valley, 2013: beach and } \\
\text { surf tourism project (e.g. Anning et al., 2013) } \\
\text { • New South Wales, Port Stephens, 2005-2007: Great } \\
\text { lakes Marine Park Zoning Plan }\end{array}$ & \\
\hline $\begin{array}{l}\text { Conservation } \\
\text { of marine } \\
\text { areas and } \\
\text { species }\end{array}$ & $\begin{array}{l}\text { - South Australia, 2005-2012: design and } \\
\text { implementation of } 19 \text { marine protected areas } \\
\text { through the use of Marxan software with layer } \\
\text { of ESV work (Kirkman, 2013a) } \\
\text { - New South Wales, Batemans Marine Park, } \\
\text { 2006: economic valuation of fisheries industries } \\
\text { in the establishment of the marine park }\end{array}$ & $\begin{array}{l}\text { - Victoria, Western Port Bay, 2004-2012: review of } \\
\text { mangrove planting activities around Westernport } \\
\text { (Kirkman and Boon, 2012) } \\
\text { - South Australia, 2011-2013: marine park regional } \\
\text { impact statements, including economic impacts } \\
\text { (Kirkman et al., 2012) } \\
\text { - New South Wales, 2008/2009: values placed by } \\
\text { stakeholders on marine parks used in marine park } \\
\text { zoning plan review (phone surveys) } \\
\text { - South Australia, 2012: commercial fishing economic } \\
\text { values from catch and effort displaced due to } \\
\text { establishment of marine parks }\end{array}$ & $\begin{array}{l}\text { - Queensland, southern Great Barrier Reef } \\
\text { and Hervey Bay/Tin Can Bay, 1998: } \\
\text { establishment of buy out schemes for } \\
\text { dugong protected area as part of the } \\
\text { Structural Adjustment Package from } \\
\text { Commonwealth Government } \\
\text { - South Australia, 2000s: the Native } \\
\text { Vegetation council applied an offset for } \\
\text { seagrass loss during a development } \\
\text { application, taking stock on estimated } \\
\text { seagrass economic values (seagrass } \\
\text { workshop 2001). }\end{array}$ \\
\hline
\end{tabular}




\begin{tabular}{|c|c|c|c|}
\hline $\begin{array}{l}\text { Coastal } \\
\text { Development }\end{array}$ & $\begin{array}{l}\text { - Victoria, Port of Hastings, 2013: impact of } \\
\text { proposed Port of Hastings Expansion on } \\
\text { Seagrass Mangroves and Saltmarsh (Kirkman, } \\
\text { 2013) } \\
\text { - New South Wales, Eurobella and Wooli } \\
\text { Village, 2010-current: ESV considered during } \\
\text { the development of coastal zone management } \\
\text { plans }\end{array}$ & $\begin{array}{l}\text { - South Australia: ESV specifically included in coastal } \\
\text { management plans (e.g. Adelaide Living Beaches. A } \\
\text { Strategy for 2005-2025) } \\
\text { - South Australia: aquaculture zone policy development } \\
\text { - New South Wales, Byron Shire, 2000-2010: Coastal } \\
\text { Coastline Management Study with cost benefit analysis } \\
\text { of management options (WBM Oceanics Australia } \\
\text { report, 2004) } \\
\text { - New South Wales, Byron Bay, } 2014 \text { Cost Benefit } \\
\text { Analysis to be undertaken for the development of the } \\
\text { Byron Bay Embayment Coastal Management Study }\end{array}$ & $\begin{array}{l}\text { - Commonwealth: current Protection of key } \\
\text { commercial fishing grounds and } \\
\text { compensation for displacement for } \\
\text { marine reserve network } \\
\text { - Commonwealth: current National } \\
\text { environmental offsets policy, although } \\
\text { the method for calculations is not } \\
\text { specified except for a few matters of } \\
\text { national environmental significance. }\end{array}$ \\
\hline $\begin{array}{l}\text { Coastal and } \\
\text { marine } \\
\text { pollution }\end{array}$ & $\begin{array}{l}\text { - South Australia, 2011-current: economic impact } \\
\text { of seagrasses and mangroves degradation } \\
\text { - New South Wales, 2000s-current: costs of } \\
\text { pollution have been considered within the Clean } \\
\text { Beach Challenge }\end{array}$ & $\begin{array}{l}\text { Queensland, Gold Coast, 2007: land development } \\
\text { guidelines for gross pollution traps as part of public } \\
\text { estate (coastal waterways) }\end{array}$ & \\
\hline $\begin{array}{l}\text { Indigenous } \\
\text { and } \\
\text { customary } \\
\text { use }\end{array}$ & $\begin{array}{l}\text { - New South Wales, 2012: value of Indigenous } \\
\text { commercial fisheries } \\
\text { - Queensland, Gold Coast, 1995: Tallebudgera } \\
\text { Greenspace } \\
\text { - Western Australia, South-West, 2000s-current: } \\
\text { Indigenous values of coastal and marine } \\
\text { environment into marine conservation planning } \\
\text { and management (e.g. Stewart, 2003) }\end{array}$ & & \\
\hline
\end{tabular}




\section{Table 5 Australian case studies where ESV was considered to have a significant impact on policy or management by coastal and marine}

\section{decision makers}

\begin{tabular}{|c|c|}
\hline With readily accessible reference & With no readily accessible reference \\
\hline $\begin{array}{l}\text { Queensland, Great Barrier Reef Marine Park valuation studies used among others for } \\
\text { marine park zoning } \\
\text { Stoeckl et al., } 2011 \text { for a review of valuation works }\end{array}$ & $\begin{array}{l}\text { Queensland, Great Barrier Reef Marine Park (GBRMP) commercial fisheries buy- } \\
\text { backs and GBRMP representative areas }\end{array}$ \\
\hline $\begin{array}{l}\text { South Australia, Adelaide costs and benefits of seagrass meadows to coast protection } \\
\text { and beach and harbour management } \\
\text { Deans and Murray-Jones, } 2002\end{array}$ & $\begin{array}{l}\text { South Australia } \\
\text { - Development of marine parks and its impact on fishing activities; } \\
\text { - Economic contributions of aquaculture development when considering } \\
\text { development proposals. }\end{array}$ \\
\hline $\begin{array}{l}\text { Queensland, Gold coast, } 1997 \text { costs and benefits of beach nourishment and } \\
\text { restoration } \\
\text { Maitra and Walker, } 1972\end{array}$ & $\begin{array}{l}\text { Western Australia } \\
\text { - Since } 1995 \text { ESV were used in Environmental Protection Agency policies } \\
\text { concerning Cockburn Sound area; } \\
\text { - Pilbara mining valuation studies. }\end{array}$ \\
\hline $\begin{array}{l}\text { South Australia, } 2012 \text { economic impacts of marine parks zoning } \\
\text { Econsearch et al. } 2012 .\end{array}$ & $\begin{array}{l}\text { Western and Southern Rock Lobster fisheries use of ESV for Maximum Economic } \\
\text { Yield and translocation }\end{array}$ \\
\hline $\begin{array}{l}\text { Queensland, Moreton Bay, 2012. Harvest strategy evaluations and co-management } \\
\text { for the Moreton Bay Trawl Fishery } \\
\text { Courtney et al. } 2012\end{array}$ & Tasmania bioeconomics of Giant crab management changes \\
\hline $\begin{array}{l}\text { Western Australia, Ngari Capes Marine Park, } 2006 \text { Abalone survey (biomass and } \\
\text { annual commercial catches) } \\
\text { Work conducted by Murdoch University in } 2006 \text { for the Departments of Fisheries } \\
\text { and Environment and Conservation in Western Australia (Loneraga et al.) }\end{array}$ & $\begin{array}{l}\text { Social and Economic Long Term Monitoring Programme within the National } \\
\text { Environmental Research Program (early stage) }\end{array}$ \\
\hline
\end{tabular}




\section{Reasons why ESV is not used in decision making}

When asked if they had been involved in a decision-making process where ESV information existed but was not used, only six per cent of respondents answered "Yes, often", 10 per cent answered "Yes, a few times", 47 per cent answered "Never" and 37 per cent declared that they did not know.

Respondents who answered "yes, often" or "yes, a few times" were then asked to choose among a list of possible reasons why existing ESV information was not used. Their answers, by decreasing order of frequency of choice, were that decision makers preferred to base decision-making on other types of information (for nine respondents out of 11), that the information was not perceived as robust enough or that the decision-making framework/guidelines did not allow this information to be used (five out of 11), that the information was not relevant to the need of decision makers or management (four out of 11), and finally that the information was not accessible (one out of 11). A small number of respondents added that this was also due to the resistance from industry or other bodies, since the use of ESV information would have hindered development. An individual mentioned that "ESV is understood as a technique but there is no political will to back it up".

In relation to a coastal zone management planning process, a respondent stated "ESV info available was very coarse and subjective and therefore only given limited weight in the decision making process". Another respondent indicated that the existing literature of ESV for estuaries is not used in decision-making processes on the NSW South Coast. Other respondents indicated that ESV of seagrass is often ignored in spatial planning for aquaculture in South Australia (SA), for example when approving dredging for marina entrances or boat ramps. Another respondent, again referring to SA, mentioned that the numerous reports that have been produced on various issues such as economic indicators on fisheries or impact assessments of marine parks have rarely been used in SA management decisions. Another 
example related to the selective use of existing ESV information about the Ningaloo marine park in Western Australia. Two respondents stressed that ESV could have been used on several occasions in marine park planning processes since 1997 and in assessing ports dredge impacts in Queensland.

\section{Discussion and conclusion}

The survey results show that, in cases where ESV information was available, it seemed to rarely be ignored. This may come as a rather comforting observation for ESV practitioners, and may be linked to the efforts dedicated to the development of ESV during the last two decades, both theoretical and methodological, as well as to its implementation in decisionmaking.

Results show that ESV is being used in coastal and marine management in Australia, mostly as a way to communicate and raise awareness, and as a way to support evaluation and discussion during decision-making processes, in a range of management contexts. ESV is much less frequently used when establishing economic or financial instruments, or as a basis for compensation. This observation concurs with the literature showing that ESV does not seem to play an important role in setting prices, or levels of instruments such as payments for ecosystem services or access fees (e.g. Liu et al., 2010). It could also be related to the fact that the use of economic instruments for the management of marine and coastal ecosystem uses is not widespread, other than in selected cases such as commercial fishing rights or permits for recreational activities in marine protected areas. In the survey, the few specific examples cited by decision-makers mostly referred to specific damage compensation, where ESV was considered among other information in implementing offsets, as well as in marine park buyback programs for commercial fisheries. 
The frequency with which the survey respondents perceived ESV was being used also seemed to vary substantially depending on the management contexts. On average use was perceived to decrease across the following management contexts: commercial fisheries (where ESV was mostly cited as being frequently used), recreational activities and tourism, coastal development, marine areas and species conservation, coastal and marine pollution (where ESV was mostly cited as being rarely used), and indigenous and customary use issues (mostly cited as never being used).

Even though ESV was seen to be considered in decision-making processes, it was rarely perceived as having a significant impact on policy or management decisions. The examples of strong ESV impacts that were mentioned were limited to the context of commercial fisheries management around Australia, as well as marine park zoning and its implementation.

The measure of ESV impact used in the survey (whether this was considered to be "significant") was relatively coarse and did not allow a more precise understanding of the specific impacts of ESV on decision-making. However, this result shows that, globally, while considered, the information conveyed by ESV was not perceived as critical in the design, adoption or implementation of management/policy measures regarding coastal and marine ecosystems. This warrants a more detailed evaluation of the specific impacts of ESV in practical decision-making, which is beyond the scope of this work.

These results - that ESV is rarely ignored and is being used, but that it has a limited impact on policy - may seem contradictory. In this survey, "ESV use" means that it is considered as an input in the decision-making process in various ways (mentioned in discussions, used for advocacy, used in assessing trade-offs, etc.), alongside other indicators or decision criteria. The impact assessment then focuses on whether:

- ESV is not perceived to play a major role in decision-making; 
- ESV is perceived to have a significant influence on the final decision.

As with any tool, the availability of ESV and the fact that it is used at some stage in the decision process does not necessarily mean that it contributes greatly to decision-making. This may be because:

i. While ESV is initially perceived as a useful tool by decision-makers (and presented as such by practitioners), hence considered at some stage in the decision process, it is ultimately not seen to effectively inform policy or management decision-making as much as other sources of information (e.g. ecological indicators);

ii. The information provided by ESV is used inadequately in decision-making, with limited effects on the outcomes of the decision-making process. This may refer to an inefficient utilization (e.g. ESV is simply mentioned in discussions while it could have been used more effectively integrated in a cost benefit analysis) or to a misunderstanding of the information provided (e.g. valuation technique and related hypothesis).

iii. While ESV is effectively used to inform decision-making, its final impacts on decisions are strongly linked to external factors (e.g. relating to the legal context, or to political agendas).

Of the more than 80 examples and references provided by the decision-makers in the survey, only a few academic publications in peer-reviewed journals were cited (mostly by researchers or scientists), less frequently than consultancy and research reports produced for government or other organisations. In addition, several respondents referred to an "informal use" of internal evaluations, which were not published or accessible. This highlights the substantial role played by the grey literature (such as reports, policy briefs, or other non-academic documents) in providing information to decision-makers, in comparison to peer-reviewed publications. This concurs with the observation that many stakeholders involved in decision- 
making processes (especially at the policy level) rarely consult articles published in peerreviewed journals (Gibbons et al. 2008). It also concurs with the fact that many academic ESV publications do not focus on the potential uptake and subsequent utilization of their results by decision-makers (Laurans et al., 2013b). It is also consistent with the possibility that the peer-reviewed literature on coastal and marine ESV is still insufficiently developed so that more reliable valuation work is needed to support the needs of coastal and ocean managers and policy analysts (Pendleton et al., 2007). The limited role of peer-reviewed literature could finally be a consequence of the fact that "academic economists can prioritise activities (or are required to prioritise activities) that would exacerbate their isolation from potential non-academic end-users of their research" (Cherney et al., 2013, p.14). The novelty and technique required for a peer-reviewed publication can be inconsistent with needs of policymakers.

However, it is worth noting that a substantial number of grey literature references cited by the decision-makers did correspond to work conducted by researchers from universities or other institutions. Decision-making tools such as INVEST or ESV databases were also mentioned in comments and examples by some of the decision-makers working in policy and management. This tends to accord with the increasing efforts of ESV practitioners to engage with decision-making and policy (e.g. Rogers et al., 2013; Balmford et al., 2011; de Groot et al., 2010; Daily et al., 2009).

Although it is clear that the decision-makers in the sample seemed to have a rather good awareness of ESV, several comments and examples showed that there was confusion about what was actually measured by ESV (e.g. profits versus added value, marginal versus nonmarginal values, or consumer surplus versus social perceptions), and between ESV and other approaches such as cost-effectiveness or socio-economic impact studies. This could concord with the hypothesis that decision-makers might have insufficient general training in 
economics (Driml, 1997 with a focus on Australia; Laurans et al., 2013b for a more general perspective), and a lack of specific knowledge regarding non-market valuation, as found by Rogers et al. (2013) in Australia.

This article provides a first expert-based review of the extent to which economic valuation is used in decision-making processes associated with the management of coastal and marine systems in Australia. More work is needed to fill the gap in the academic literature about the practical value and use of ecosystem services valuation, in the marine context and beyond. This research relied on the experience and recall of decision-makers to identify cases in which ESV has been used and a more broadly based literature review is also clearly needed with a focus on the grey literature. In addition, there is a need to continue building bridges between decision-making needs and research in this field. This emphasizes the importance of proposed strategies and practices to enhance collaborations between researchers and decision-makers, as well as research transfer, uptake and impact within policy contexts (Cherney et al., 2013; Rogers et al., 2013; Pendleton et al., 2007). 


\section{Acknowledgements}

The data used in this manuscript were derived from a survey supported by the Marine Biodiversity Hub of the Australian Government's National Environmental Research Program. Within the Hub, the authors are grateful to Dr Nic Bax from CSIRO and Paul Hedge from University of Tasmania for their help in supporting and setting up the survey. The authors are also grateful to the CSIRO Wealth from Ocean flagship for supporting this work, as well as the Australian Fisheries Research Development Corporation (FRDC project 2008/306). The authors thank all the individuals that participated in the surveys. The opinions expressed in this publication are those of the authors. They do not reflect the opinions of the organizations they work for, and do not indicate a commitment from these organizations to a course of action. 


\section{Appendix A: Stated frequency for the different types of ESV use and management contexts}

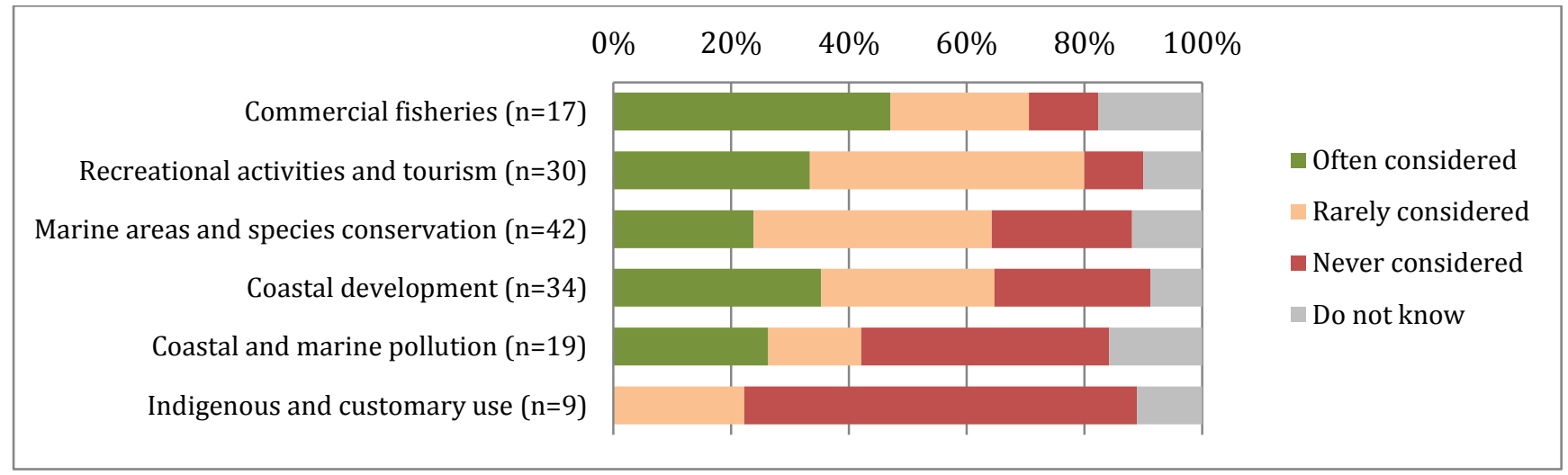

Figure A1 Stated use of ESV as a way to communicate, advocate or raise awareness, by different management context

\begin{tabular}{|c|c|c|c|c|c|c|}
\hline & $20 \%$ & $40 \%$ & $60 \%$ & $80 \%$ & $100 \%$ & \multirow{7}{*}{$\begin{array}{l}\square \text { Often considered } \\
\text { Rarely considered } \\
\square \text { Never considered } \\
\square \text { Do not know }\end{array}$} \\
\hline \multicolumn{6}{|l|}{ Commercial fisheries $(n=17)$} & \\
\hline \multicolumn{6}{|l|}{ Recreational activities and tourism $(n=30)$} & \\
\hline \multicolumn{6}{|l|}{ Marine areas and species conservation $(n=42)$} & \\
\hline \multicolumn{6}{|l|}{ Coastal development $(n=34)$} & \\
\hline \multicolumn{6}{|l|}{ Coastal and marine pollution $(n=19)$} & \\
\hline Indigenous and customary use $(n=9)$ & & & & & & \\
\hline
\end{tabular}

Figure A2 Stated use of ESV for evaluation and decision-making, by different management context

\begin{tabular}{|c|c|c|c|c|c|c|}
\hline 0 & $20 \%$ & $40 \%$ & $60 \%$ & $80 \%$ & $100 \%$ & \multirow{6}{*}{$\begin{array}{l}\square \text { Often considered } \\
\text { Rarely considered } \\
\square \text { Never considered } \\
\square \text { Do not know }\end{array}$} \\
\hline \multicolumn{6}{|l|}{ Commercial fisheries $(n=17)$} & \\
\hline \multicolumn{6}{|l|}{ Recreational activities and tourism $(n=30)$} & \\
\hline \multicolumn{6}{|l|}{ Marine areas and species conservation $(n=42)$} & \\
\hline \multicolumn{6}{|l|}{ Coastal development $(n=34)$} & \\
\hline \multicolumn{6}{|l|}{ Coastal and marine pollution $(n=19)$} & \\
\hline Indigenous and customary use $(n=9)$ & & & & & & \\
\hline
\end{tabular}

Figure A3 Stated use of ESV for establishing taxes, subsidies, fees or damage compensation, by different management context 


\section{References}

Anning, D., Ware, D., Raybould, M. and Lazarow, N. (2013). Valuing beach and surf tourism and recreation in Australian sea change communities. 4th Queensland Coastal Conference. Townsville, Queensland.

Balmford, A., Fisher, B., Green, R.E., et al. (2011). Bringing ecosystem services into the real world: an operational framework for assessing the economic consequences of losing wild nature. Environmental and Resource Economics 48, 161-175.

Barbier, E.B. (2012). Progress and Challenges in Valuing Coastal and Marine Ecosystem Services. Review Environmental Economics and Policy 6(1), 1-19.

Bennett, J. (2011). Valuing Australia's Environment. Australasian Journal of Environmental Management 1(1), 21.

Brander, L. Van Beukering, M., P., and Cesar, H.S.J. (2007). The recreational value of coral reefs: A meta-analysis. Ecological Economics 62, 209-218.

Briggs, S.V. (2006). Integrating policy and science in natural resources: why so difficult?, Ecological Management and Restoration 7(1), 37-39.

Cherney, A., Head, B., Boreham, P., Povey, J., and Ferguson, M. (2013). What influences the utilisation of economics research? - The perspectives of academic researchers. Project working paper,Institute for Social Science Research, The University of Queensland.

Courtney, A.J., Kienzle, M., Pascoe, S. et al. (2012). Harvest strategy evaluations and comanagement for the Moreton Bay Trawl Fishery. Australian Seafood CRC Project 2009/774

Daily, G.C., Polasky, S., Goldstein, J., et al. (2009). Ecosystem services in decision making: time to deliver. Frontiers in Ecology and the Environment 7(1), 21-28

de Groot, R.S., Alkemade, R., Braat, L. et al. (2010). Challenges in integrating the concept of ecosystem services and values in landscape planning, management and decision making. Ecological Complexity 7, 260-272.

Deans, J., and Murray-Jones, S. (2002) Value of Seagrass Meadows to the Metropolitan Adelaide Coast. In Kench, Paul S. (Editor); Hume, Terry M (Editor). Coasts \& Ports 2003 Australasian Conference 
Driml, S. (1997). Bringing ecological economics out of the wilderness. Ecological Economics 23(2), 145-153.

Econsearch et al. (2012). Marine Park Regional Impact Statements Main Report. Report prepared for South-Australian Department of Environment, Water and Natural Resources

Ezzy, E. and Scarborough, H. (2011). Estimation of the Recreational Use Value Gained from Recreational Fishing of Southern Bluefin Tuna at Portland, Australia. Australian Agricultural and Resource Economics Society $55^{\text {th }}$ Conference, Melbourne.

Gao, L., and Hailu, A. (2011). Evaluating the effects of area closure for recreational fishing in a coral reef ecosystem: The benefits of an integrated economic and biophysical modelling. Ecological Economics 70(10): 1735-1745.

Gibbons, P., Zammit, C., Youngentob, K., et al. (2008). Some practical suggestions for improving engagement between researchers and policy- makers in natural resource management, Ecological Management and Restoration 9(3), 182-186.

Hutton, T., Thebaud, O., Fulton, E., et al. (2010). Use of Economic Incentives to Manage Fisheries Bycatch: An Application to Key Sectors in Australia's Southern and Eastern Scalefish and Shark Fisheries. CSIRO.

Kirkman, H. (2011). Seagrasses \& mangroves. In: Vulnerability of South Australian Marine Habitats. Marine Parks, Department of Environment, Water and Natural Resources South Australia. $30-35 \& 65-71$.

Kirkman, H. and Boon, P. (2012). Review of Mangrove Planting Activities around Westernport 2004-2011. Report to Western Port Seagrass Partnership Inc. 43 pp.

Kirkman, H., Bryars, S..and Brook, J. (2012). Marine Park Regional Impact Statements Main Report Department of Environment. Water and Natural Resources, South Australia. 283 pp.

Kirkman, H. (2013a). Choosing boundaries to marine protected areas and zoning the MPAs for restricted use and management. Journal of Ocean and Coastal Management. 81: 38-48.

Kirkman H. (2013b). Impact of proposed Port of Hastings Expansion on Seagrass Mangroves and Saltmarsh. Report to Victorian National Parks Association Inc. 35 pp. 
Kushner B., Waite, R., Jungwiwattanaporn, M., and Burke, L. (2012). Influence of coastal economic valuation in the Caribbean: enabling conditions and lessons learned. World Resource Institute, Working paper.

Laurans, Y., Pascal, N., Binet, T., et al. (2013a). Economic valuation of ecosystem services from coral reefs in the South Pacific: taking stock of recent experience. Journal of Environmental Management 116, 135-144.

Laurans, Y., Rankovic, A., Mermet, L., Billé, R., and Pirard, R. (2013b). Actual use of ecosystem services valuation for decision-making: questioning a literature blindspot. Journal of Environmental Management 119, 208-219.

Liu, S., Costanza, R., Farber, S., and Troy, A. (2010). Valuing ecosystem services Theory, practice, and the need for a transdisciplinary synthesis, Ann. N.Y. Acad. Sci. 1185, 54 78.

Maitra, A. K., and Walker, K. E. (1972). An Economic Appraisal of the Restoration of Gold Coast Beaches. Report to Gold Coast City Council and Queensland State Government.

Pendleton, L., Atiyah, P., Moorthy, A. (2007). Is the non-market literature adequate to support coastal and marine management? Ocean \& Coastal Management 50, 363-378.

Raguragavan, J., Hailu, A., and Burton, M.P. (2013). Economic valuation of recreational fishing in Western Australia: Statewide random utility modelling of fishing site choice behaviour. Australian Journal of Agricultural and Resource Economics 57(4), 539-558.

Rogers, A.A., Kragt, ME.., Gibson, F.L., Petersen, E.H., and Pannell, D.J. (2013). Nonmarket valuation: usage and impacts in environmental policy and management in Australia. Australian Journal of Agricultural and Resource Economics 57, 1-15.

Schumann, P. (2011). The Valuation of Marine Ecosystem Goods and Services in the Caribbean. Wilmington, NC: University of North Carolina Wilmington.

Stewart, S. (2003). Integrating Indigenous values and uses of the coastal and marine environment into marine conservation planning and management in the South-west of Western Australian, unpublished honours thesis, Murdoch University, Perth.

Stoeckl, N., Hicks, C.C., Mills, M. et al. (2011). The economic value of ecosystem services in the Great Barrier Reef: our state of knowledge. Ann. N.Y. Acad. Sci. 1219, 113-133. 
Waite, R., Burke, L., Gray, E., et al. (2014). Coastal Capital: Ecosystem Valuation for Decision Making in the Caribbean. Washington, DC: World Resources Institute. Accessible at: http://www.wri.org/coastal-capital. 